\title{
POST-ACTIVATION POTENTIATION AND FATIGUE IN QUADRICEPS FEMORAL MUSCLE AFTER A 5 S MAXIMAL VOLUNTARY ISOMETRIC CONTRACTION
}

\author{
Nerijus Masiulis ${ }^{1}$, Albertas Skurvydas ${ }^{1}$, Sigitas Kamandulis ${ }^{1}$, Audrius Sniečkus ${ }^{1}$, \\ Marius Brazaitis ${ }^{1}$, Laura Daniusevičiūtè $\dot{1}^{1,2}$, Irina Ramanauskienè $\dot{e}^{2}$ \\ Lithuanian Academy of Physical Education ${ }^{1}$, Kaunas University of Technology, \\ Kaunas, Lithuania
}

Nerijus Masiulis. PhD in Biomedical Sciences. Lecturer at the Department of Applied Physiology and Sports Medicine, Lithuanian Academy of Physical Education. Research interests - acute adaptation of skeletal muscle during and after short time exercise.

\begin{abstract}
Following an acute physical exercise, both post-activation potentiation and fatigue of the neuromuscular apparatus may occur. The voluntary recruitment of motor units occurs with frequencies that elicit incompletely fused tetanic contractions and these frequencies are most susceptible for post-activation potentiation as well as low-frequency fatigue. Therefore, the goal of the present study was to investigate which of the processes post-activation potentiation or low-frequency fatigue will be prevalent after 5 s maximal voluntary contraction $(M V C)$.

Eight healthy untrained men (age 24-35 years, mass $81.2 \pm 5.1 \mathrm{~kg}$ ) performed maximal sustained isometric knee extension for $5 s$ at a knee angle of 90 degrees. The contractile properties of quadriceps muscle evoked by electrical stimulation at 1, 7, 10, 15,20,50 Hz and $100 \mathrm{~Hz}$, were recorded before and immediately after the exercise and 3, 5, and 10 min following the exercise. The rest interval between muscle electrical stimulation was $3 \mathrm{~s}$.

A significant raise of force evoked by $1-15 \mathrm{~Hz}$ stimulation was observed immediately after the $5 \mathrm{~s}$ MV exercise $(p<0.01)$. Later in recovery (at $10 \mathrm{~min}$ ) the contraction force at $15 \mathrm{~Hz}$ and $20 \mathrm{~Hz}$ significantly decreased $(p<0.05)$. Tetanic force at $50 \mathrm{~Hz}$ and $100 \mathrm{~Hz}$ demonstrated a significant decrease immediately after the exercise and remained depressed up to $3 \mathrm{~min}(p<0.01)$. The ratio of $20 / 50 \mathrm{~Hz}$ recorded immediately after the $5 \mathrm{~s} M V \mathrm{C}$ increased significantly $(p<0.05)$, however $10 \mathrm{~min}$ after the exercise there was a significant decrease compared to its initial level $(p<0.05)$.

The simultaneous occurrence of post-activation potentiation at low stimulation frequencies and suppressed forces at high stimulation frequencies suggests that potentiation and fatigue mechanisms were acting concurrently. Moreover, when post-activation potentiation is lost (in $10 \mathrm{~min}$ after the $5 \mathrm{~s} M V C$ exercise), the contraction force at low stimulation frequencies decreases resulting in significant low-frequency fatigue.
\end{abstract}

Keywords: isometric exercise, electrical stimulation, low-frequency fatigue, recovery.

\section{INTRODUCTION}

$\mathrm{F}$ ollowing an acute stimulus, both post-activation potentiation (PAP) and fatigue of the neuromuscular apparatus may occur (Baudry, Duchateau, 2004; Masiulis et al., 2006). In contrast to fatigue, which serves to impair force production, there is evidence that the contractile activity of skeletal muscle may facilitate the production of force - this phenomenon is known as post-activation potentiation (PAP). Few mecha- nisms have been proposed to explain this phenomenon. These mechanisms are phosphorylation of the regulatory light chains on the myosin head (Sweeney et al., 1993), elevation of $\mathrm{Ca}^{2+}$ in the cytosol (Allen et al., 1989), and reflex potentiation in the spinal cord (Hodgson et al., 2005).

A particular type of fatigue referred to as lowfrequency fatigue (LFF) is observed by a reduction in force observed at low frequencies of stimulation 
(Edwards et al., 1977). During voluntary muscle contractions in vivo individual motor units usually fire at rates between $5 \mathrm{~Hz}$ and $30 \mathrm{~Hz}$ (De Ruiter et al., 2004) which is exactly within the range of frequencies that LFF manifests itself when electrical stimulation is applied (Edwards et al., 1977; Ratkevicius et al., 1998). Therefore, the production of LFF may have significant implications for muscular function.

Stimulation at high frequencies, as used in other experiments (e. g. Tubman et al., 1996; O'Leary et al., 1997), elicits a tetanic contraction resulting from a sustained increase in intracellular $\mathrm{Ca}^{2+}$ that is maintained throughout the period of stimulation (Tubman et al., 1996). These studies demonstrated that elevation of intracellular $\mathrm{Ca}^{2+}$ can apparently activate myosin light chain kinase during sustained muscle contraction. However, this type of tetanus rarely, if ever, occurs in vivo.

Considering that voluntary recruitment of motor units occurs with frequencies that elicit incompletely fused tetanic contractions (De Ruiter et al., 2004) and these frequencies are most susceptible for PAP as well as LFF, we hypothesize that contractility of skeletal muscle during and after brief high intensity exercises is determined by interaction between the mechanism mediating PAP and fatigue. Therefore, the goal of the present study was to investigate which of the phenomenon's PAP or LFF will be prevalent during and after a brief (5 s) MVC.

\section{METHODS}

Subjects. Eight healthy untrained men (age $24-35$ years, mass $81.2 \pm 5.1 \mathrm{~kg}$ ) gave their informed consent to participate in this study. The subjects were physically active but did not take part in any formal physical exercise or sport program. Each subject read and signed written informed consent form consistent with the principles outlined in the Declaration of Helsinki.

Force Measurements. The equipment and technique used for measuring force were the same as used in the previous studies (Skurvydas, Zachovajevas, 1998; Masiulis et al., 2006). Briefly, before the performing explosive strength training session the subjects were seated in a steel framed straight-backed adjustable chair and appropriate adjustments were made to ensure an optimal riding position. A seatbelt attached to the side of the chair passed around the subject's waist and chest to firmly secure the pelvis and upper body for minimizing uncontrolled movements. The right leg was clamped in a force-measuring device with the knee kept at an angle of $90^{\circ}$ (full extension being $180^{\circ}$ ) during the whole experiment. A $6-\mathrm{cm}-$ wide plastic cuff, placed around the right leg just proximal to the malleoli, was tightly attached to a linear variable differential transducer. The output of the transducer, proportional to isometric knee extension force, was amplified and digitized at a sampling rate of $1 \mathrm{kHz}$ by a 12-bit analogue-todigital converter incorporated in a personal computer. The digitized signal was stored on a hard disk for subsequent analysis. The output from the force transducer was also displayed on a voltmeter in front of the subject. Maximal voluntary contraction (MVC) force was determined.

Electrical Stimulation. A high-voltage stimulator (MG 440, Medicor, Budapest, Hungary) was used to deliver electrical stimuli to the quadriceps muscle through surface electrodes $(9 \times 18 \mathrm{~cm})$ padded with cotton cloth and soaked in saline solution. One stimulation electrode was placed just above the patella, while another one covered a large portion of the muscle belly in the proximal third of the thigh. The electrical stimulation was always delivered in trains of square wave pulses of $1 \mathrm{~ms}$ duration (voltage $150 \mathrm{~V}$, which induces approximately $60-80$ percent of MVC). To maximize recruitment of fibres, the highest possible stimulation voltage was employed. The subjects were familiarized with electrical stimulation during the introductory visit before the onset of experiments. We measured the contractile force of the quadriceps muscle, evoked by electrical stimulation at 1 (P 1), 7 (P 7), 10 (P 10), 15 (P 15), 20 (P 20), 50 (P 50) and $100 \mathrm{~Hz}$ (P 100) (the duration of each electrical stimulation series was $1 \mathrm{~s})$. The rest interval between muscle electrical stimulation was $3 \mathrm{~s}$.

Experimental Protocol. After 5 min rest in the experimental chair, the subject performed three MVC, separated by $1 \mathrm{~min}$. The best try was taken for evaluation. Five minutes later, the protocol of electrical stimulation was applied consisting of a $1 \mathrm{~s}$ train of pulses interspaced with $3 \mathrm{~s}$ rest. The employed frequencies of electrical stimulation were recorded in the following sequence: $\mathrm{P} 1$, P 7, P 10, P 15, P 20, P 50 and P 100. The recorded parameters were considered to be initial (Ini) ones. Two min later the subject was encouraged to perform $5 \mathrm{~s}$ MVC. Immediately after 5-s MVC $(0 \mathrm{~min}), 3,5$ and $10 \mathrm{~min}$ following the exercise, the stimulation protocol was repeated. 
Statistics. The results obtained have been processed using the methods of mathematical statistics by calculating the means $(\overline{\mathrm{x}})$ and standard deviations of mean $( \pm S D)$. The differences for repeated measures in mean values were evaluated by using Student's t-test for paired data. The level of significance of the difference between arithmetic means was considered relevant when the $p$ value was less than 0.05 . The analyses were done making use of the Microsoft Excel 2000.

\section{RESULTS}

During the recovery after $5 \mathrm{~s}$ MVC, a significant potentiation of $\mathrm{P} 1-\mathrm{P} 15$ was observed (Fig. $1-2)$. P 1 was potentiated $(p<0.01)$ immediately after the exercise, then it decreased slightly, but remained augmented at 3 and $5 \mathrm{~min}$ of recovery period (both, $\mathrm{p}<0.05$ ) (Fig. 1). Similarly, the P 7, P 10 (Fig. 1) and P 15 (Fig. 2) were augmented immediately after the exercise (all, $\mathrm{p}<0.01$ ) but potentiation persisted up to 3 min after exercise only for P 7 and P 10 (both, $\mathrm{p}<0.05)$. The contraction force at P 15 and P 20 were reduced at $10 \min (p<0.05)$ (Fig. 2).
Tetanic force at P 50 and P 100 demonstrated a significant decrease immediately after the exercise and remained depressed up to $3 \min (\mathrm{p}<0.01)$ (Fig. 3). Data analysis showed that the ratio of P 20 / P 50 recorded immediately after the 5 s MVC (Fig. 4) increased significantly $(\mathrm{p}<0.05)$, however 10 min after the exercise there was a significant decrease compared to its initial level $(p<0.05)$.

\section{DISCUSSION}

Our main finding was that after $5 \mathrm{~s}$ MVC muscle fatigue and PAP occurred simultaneously while after 10 min of recovery low-frequency fatigue (LFF) was observed. It was unexpected to find that after $5 \mathrm{~s}$ MVC exercise LFF can occur. Our results were in agreement with $\mathrm{H}$. Green and S. Jones (1989) who observed that after more strenuous isometric exercises, when potentiation is lost, LFF becomes conspicuous. However, it has to be taken into account that even after $5 \mathrm{~s}$ MVC simultaneous PAP and fatigue at high stimulation frequencies and later in recovery LFF can occur.

It has been shown, that the force at low stimulation frequencies is increased following a sustained
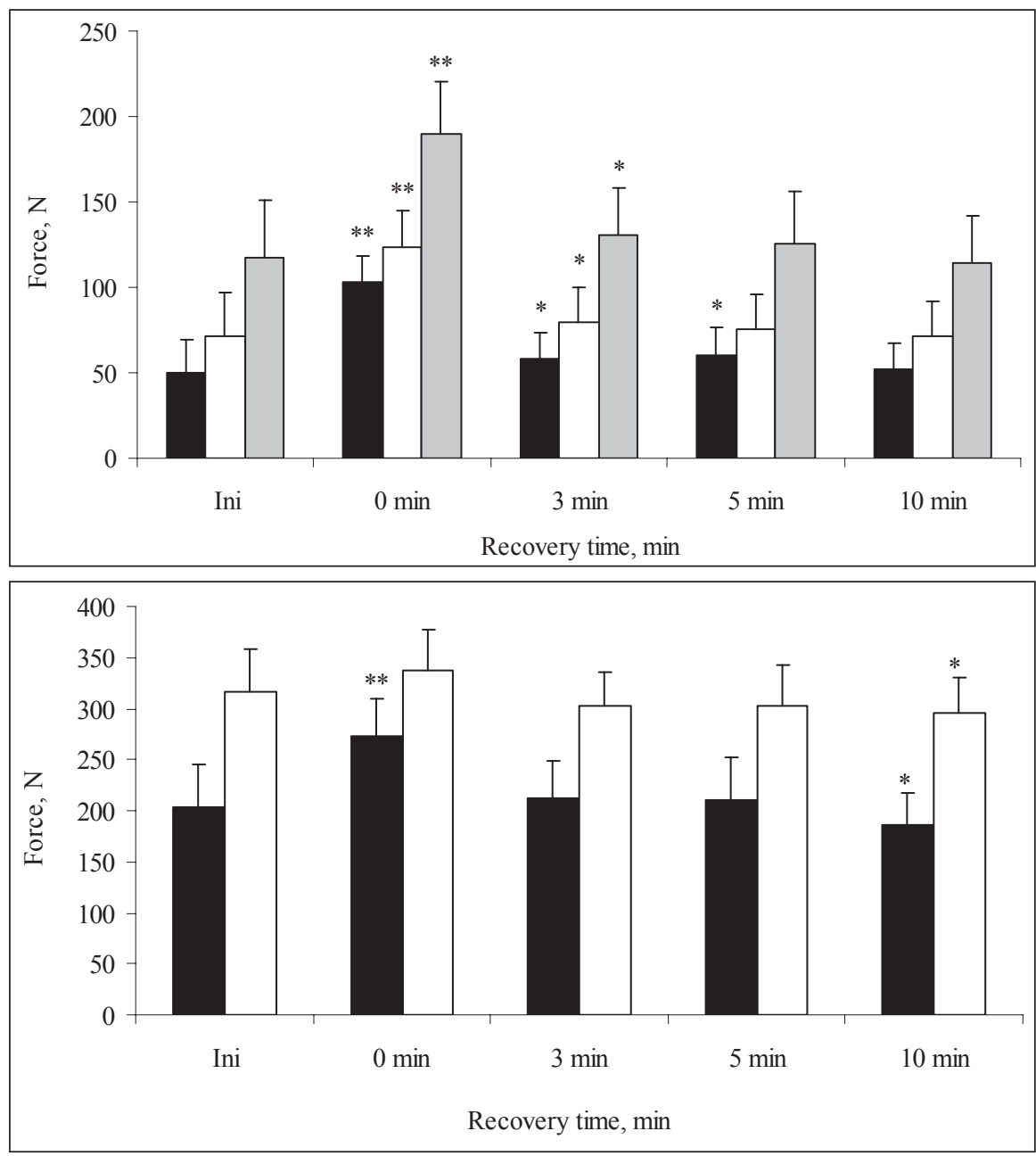

Fig. 1. The time-course of changes in $P 1, P 7$ and $P 10$ (black, white and grey bars, respectively) after sustained MVC for $5 \mathrm{~s}$ before the experiment (Ini), right after ( 0 min) and following 3,5 and $10 \mathrm{~min}$ of recovery

Note. P 1, P 7, P 10, muscle contraction force at a stimulation rate of 1,7 and $10 \mathrm{~Hz}$, respectively; Values are means \pm SD. Statistically significant differences from initial mean level (Ini) are indicated as: ${ }^{*}-\mathrm{p}<0.05 ;{ }^{*} * \mathrm{p}<0.01$ $(\mathrm{n}=8)$.

Fig. 2. The time-course of changes in $P 15$ and $P 20$ (black and white bars, respectively) after sustained $\mathrm{MVC}$ for $5 \mathrm{~s}$ before the experiment (Ini), right after $(0 \mathrm{~min})$ and following 3,5 and $10 \mathrm{~min}$ of recovery

Note. P 15, P 20, muscle contraction force at a stimulation rate of 15 and $20 \mathrm{~Hz}$, respectively; Values are means $\pm \mathrm{SD}$. Statistically significant differences from initial mean level (Ini) are indicated as: $*-\mathrm{p}<0.05 ; * *-\mathrm{p}<0.01(\mathrm{n}=8)$. 
Fig. 3. The time-course of changes in $P 50$ and $P 100$ after sustained MVC for $5 \mathrm{~s}$ before the experiment (Ini), right after (0 $\mathrm{min})$ and following 3,5 and $10 \mathrm{~min}$ of recovery
Note. P 50, P 100, muscle contraction force at a stimulation rate of 50 and $100 \mathrm{~Hz}$, respectively; Values are means \pm SD. Statistically significan differences from initial mean level (Ini) are indicated as: $*-\mathrm{p}<0.05$; ** — $\mathrm{p}<0.01(\mathrm{n}=8)$.

Fig. 4. The time-course of changes in $\mathbf{P} 20 / \mathbf{P} 50$ ratio after sustained MVC for $5 \mathrm{~s}$ before the experiment (Ini), right after ( $0 \mathrm{~min})$ and following 3,5 and $10 \mathrm{~min}$ of recovery

Note. P 20 and P 50, muscle conof $20 \mathrm{~Hz}$ and $50 \mathrm{~Hz}$ respectively; Values are means \pm SD. Statistically significant differences from initial mean level (Ini) are indicated as: $*$ - $\mathrm{p}<0.05(\mathrm{n}=8)$. traction force at a stimulation rate
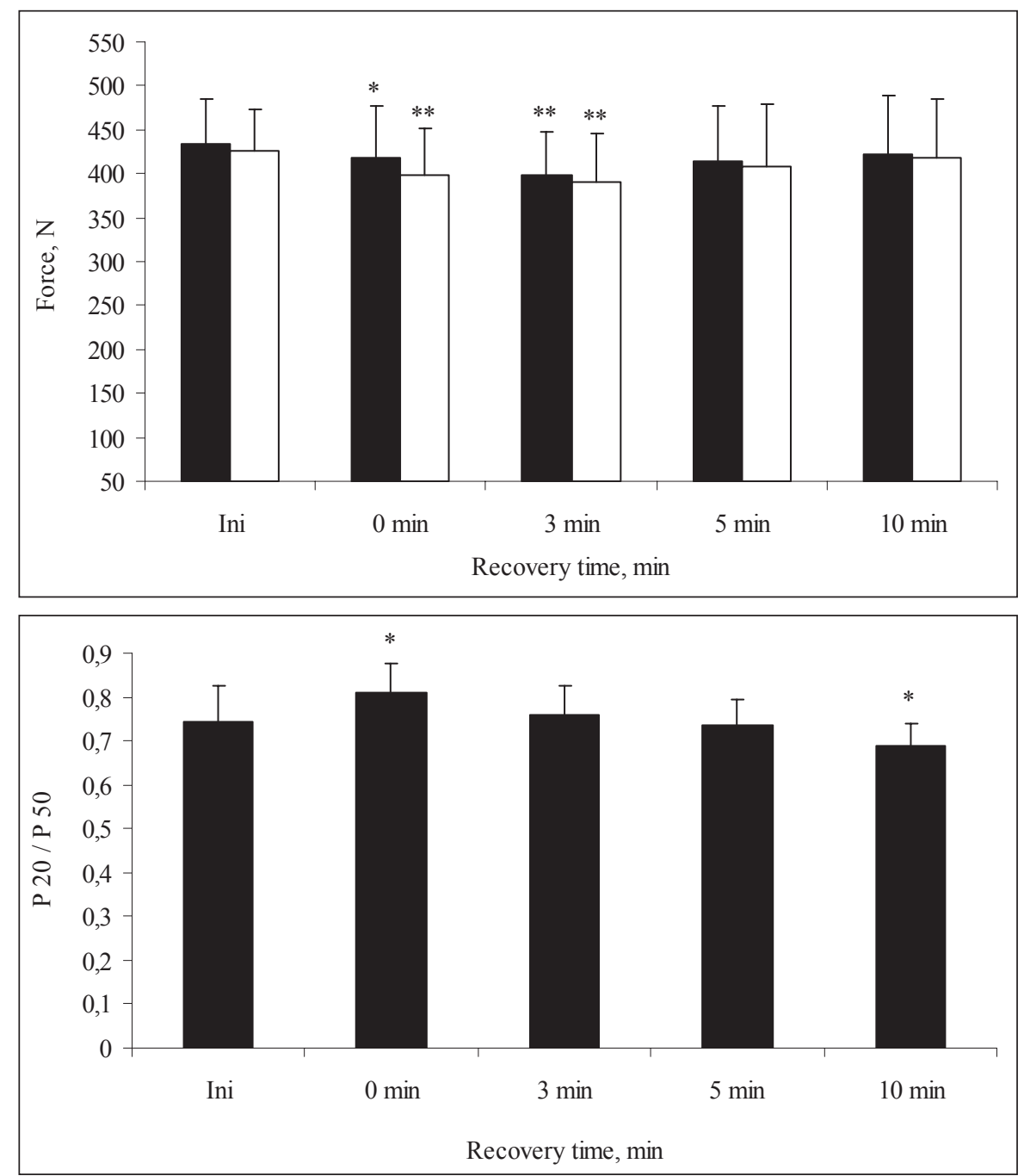

MVC (Skurvydas, Zachovajevas, 1998; Baudry, Duchateau, 2004). Our results are in agreement with this observation, as, after brief MVC, we found potentiation in contractile responses up to $15 \mathrm{~Hz}$ of electrical stimulation (Fig. 1-2).

Some authors observed potentiation with intermittent contractions at $40 \mathrm{~Hz}$ in rat gastrocnemius muscle (MacIntosh, Willis, 2000), cat tibialis posterior muscle (Bevan et al., 1993), and cat gastrocnemius muscle (Burke et al., 1976). However, in their case, fatigue was not a limiting factor for potentiation. While in our case, we did not see potentiation of contractions elicited with $20 \mathrm{~Hz}$ stimulation, but the fatigue that was evident immediately and following 3 min after $5 \mathrm{~s} \mathrm{MVC}$ at high stimulation frequencies (Fig. 3) may have masked potentiation that otherwise might have been evident at P 20 (Fig. 2).

Notably, the force loss at $50 \mathrm{~Hz}$ and $100 \mathrm{~Hz}$ (Fig. 3) without depression of force at low-frequencies is considered a marker of attenuated sarcolemma excitability, which has been associated with depletion of $\mathrm{Na}^{+}$and accumulation of $\mathrm{K}^{+}$in the extracellular spaces impairing membrane depolarization especially at high frequencies (Strojnik, Komi, 1998).

When the contractile response to low-frequency stimulation is diminished (P 15 and P 20 at $10 \mathrm{~min}$ ) while at the same time the response to high-frequency stimulation is not affected, LFF is present (Edwards et al., 1977). After $5 \mathrm{~s} \mathrm{MVC,}$ LFF was identified as a decrease in the P 20 / P 50 ratio (Fig. 4). A close relationship was observed between the depressions in $\mathrm{Ca}^{2+}$ release with the extent of LFF examined after fatiguing isometric contractions of the quadriceps (Binder-Macleod, Russ, 1999). When trains of impulses arrive in quick succession, the $\mathrm{Ca}^{2+}$ is thought to accumulate in the sarcoplasm so that full cross-bridge interaction can take place once more. Although the LFF became obvious only in the later phase of recovery, a decrease in P20/P50 ratio following the $5 \mathrm{~s}$ MVC indicates that the onset of it occurs as early as 10 min after the exercise (Fig. 4).

However, previously LFF was observed after much more strenuous isometric exercises (Edwards 
et al., 1977; Ratkevicius et al., 1998). There is a possibility that in the isometric exercise with maximal intensity, the sarcomeres of the end of fibre overextend and it leads to damage. In this situation the active sarcomeres would be working at a shorter length than predicted from the overall fibre length and the force-frequency curve will be shifted to the right (Jones, 1996). We suppose that rising LFF during and after isometric exercises of maximal intensity may be linked to the damage of sarcomeres. Therefore, the reduction of $\mathrm{P} 7$ and P 10 forces would be expectable in the case of LFF. However, with the present data (Fig. 1) we cannot state it clearly. This discrepancy possibly can be explained, that $\mathrm{P} 7$ and $\mathrm{P} 10$ forces are augmented because of PAP, while P 15 and P 20 forces are less dependent on PAP.

Three different segments in the range of stimulation frequencies may be separated according to the changes in the contraction force after $5 \mathrm{~s}$ MVC. Segment $A$ (P 1-P 10) (Fig. 1) appeared to be the most sensitive to $5 \mathrm{~s}$ MVC. In segment $B$ (P 15-P 20) (Fig. 2) there still persisted a tendency of force to potentiate when the studies with 10-s MVC showed the reduction of force (Green, Jones, 1989). We speculate that $P 20$ force is susceptible for both PAP and LFF, while P 15 is more sensitive to PAP then P 20, and, therefore, LFF in P 15 can be less evident. However, if potentiation would not be present, P 15 would be more depressed comparing to P 20. In segment $C$ (P 50-P 100) (Fig. 3), there was a significant force attenuation. Besides, the reduction of $\mathrm{P} 50$ may be partly explained by stimulation history (P 50 was recorded as the last contraction in the stimulation sequence) in addition to $5 \mathrm{~s}$ MVC. It was shown that even the sprint of 6-s duration significantly affects metabolite pattern that may account for fatigue (Dawson et al., 1978).

We speculate that segmentation is related to different net output of the effects of PAP- and fatigue-related mechanisms at distinct ranges of stimulation frequency. However, this notion will need additional research to be verified.

Summing up, the present study showed that immediately after the $5 \mathrm{~s} \mathrm{MVC}$, the simultaneous occurrence of PAP at very low and low stimulation frequencies and suppressed forces at high stimulation frequencies suggests that potentiation and fatigue mechanisms were acting concurrently. It has been shown that when potentiation is lost, LFF becomes conspicuous (Green, Jones, 1989). This finding is in agreement with our results whereas when PAP is lost the contraction force at P 15 and $P 20$ appeares to reduce at $10 \mathrm{~min}$ resulting in significant LFF.

\section{CONCLUSION}

Simultaneous occurrence of post-activation potentiation at very low and low stimulation frequencies and increased fatigue at high stimulation frequencies suggest that potentiation and fatigue mechanisms are acting concurrently immediately after brief $5 \mathrm{~s}$ MVC. Moreover, when post-activation potentiation is lost, the contraction force at low stimulation frequencies decreases resulting in significant low-frequency fatigue.

\section{REFERENCES}

Allen, D. G., Lee, J. A., Westerblad, H. (1989). Intracellular calcium and tension during fatigue in isolated single muscle fibres from Xenopus laevis. Journal of Physiology (London), 415, 433-458.

Baudry, S., Duchateau, J. (2004). Postactivation potentiation in human muscle is not related to the type of maximal conditioning contraction. Muscle \& Nerve, 30, $328-336$.

Bevan, L., Laouris, Y., Garland, S. J., Reinking, R. M., Stuart, D. G. (1993). Prolonged depression of force developed by single motor units after their intermittent activation in adult cats. Brain Research Bulletin, 30, 127-131.

Binder-Macleod, S. A, Russ, D. V. (1999). Effects of activation frequency and force on low-frequency fatigue in human skeletal muscle. Journal of Applied Physiology, 86, 4, 1337-1346.

Burke, R. E., Rudomin, P., Zajac, F. E. III. (1976). The effect of activation history on tension production by individual muscle units. Brain Research, 109, 515-529.

Dawson, M. J., Gadian, D. G., Wilkie, D. R. (1978). Mus- cular fatigue investigated by phosphorus nuclear magnetic resonance. Nature, 274, 861-866.

Edwards, R. H. T., Hill, D. K., Jones, D. A., Merton, P. A. (1977). Fatigue of long duration in human skeletal muscle after exercise. Journal of Physiology, 272, 769-778.

Green, H. J, Jones S. R. (1989). Does post-tetanic potentiation compensate for low frequency fatigue? Clinical Physiology, 9, 499-514.

Hodgson, M., Docherty, D., Robbins, D. (2005). Postactivation potentiation: Underlying physiology and implications for motor performance. Sports Medicine, 35, 7, 585-595.

Jones, D. A. (1996). High- and low-frequency fatigue revisited. Acta Physiologica Scandinavica, 156, 265-270.

MacIntosh, B. R., Willis, J. C. (2000). Force-frequency relationship and potentiation in mammalian skeletal muscle. Journal of Applied Physiology, 88, 2088-2096.

Masiulis, N., Skurvydas, A., Kamandulis, S., Kamanduliene, L. (2006). Post-activation potentiation counteracts low-frequency fatigue of quadriceps muscle during ex- 
plosive strength training session. Ugdymas. Küno kultūra. Sportas, 4, 63, 76-82.

O’Leary, D. D., Hope, K., Sale, D. G. (1997). Posttetanic potentiation of human dorsiflexors. Journal of Applied Physiology, 83, 2131-2138.

Ratkevicius, A., Skurvydas, A., Povilonis, E., Quistorff, B., Lexell, J. (1998). Effects of contraction duration on low-frequency fatigue in voluntary and electrically induced exercise of quadriceps muscle in humans. European Journal of Applied Physiology and Occupational Physiology, 77, 462-468.

De Ruiter, C. J., Elzinga, M. J. H., Verdijk, P. W. L., van Mechelen, W., de Haan, A. (2004). Voluntary drive-dependent changes in vastus lateralis motor unit firing rates during a sustained isometric contraction at $50 \%$ of maximum knee extension force. Pflügers Archiv: European Journal of Physiology, 447, 436-444.
Skurvydas, A., Zahovajevas, P. (1998). Is post-tetanic potentiation, low frequency fatigue (LFF) and post-contractile depression (PCD) coexistent in intermittent isometric exercises of maximal intensity? Acta Physiologica Scandinavica, 164, 127-133.

Strojnik, V., Komi P. V. (1998). Neuromuscular fatigue after maximal stretch-shortening cycle exercise. Journal of Applied Physiology, 84, 1, 344-350.

Sweeney, H. L., Bowman, B. F., Stull, J. T. (1993). Myosin light chain phosphorylation in vertebrate striated muscle: Regulation and function. American Journal of Physiology, 264, C 1085-1095.

Tubman, L. A., MacIntosh, B. R., Maki, W. A. (1996). Myosin light chain phosphorylation and posttetanic potentiation in fatigued skeletal muscle. Pflügers Archiv: European Journal of Physiology, 431, 882-887.

\title{
KETURGALVIO ŠLAUNIES RAUMENS POSTAKTYVACINE் POTENCIACIJA IR NUOVARGIS ATLIKUS 5 SEKUNDŽIŲ TRUKMĖS MAKSIMALAUS INTENSYVUMO IZOMETRINİ KRŪVI
}

\author{
Nerijus Masiulis $^{1}$, Albertas Skurvydas ${ }^{1}$, Sigitas Kamandulis ${ }^{1}$, Audrius Sniečkus ${ }^{1}$, \\ Marius Brazaitis ${ }^{1}$, Laura Daniusevičiūtè $\dot{e}^{1,2}$, Irina Ramanauskiene் $\dot{e}^{2}$ \\ Lietuvos kūno kultūros akademija ${ }^{1}$, Kauno technologijos universitetas ${ }^{2}$, Kaunas, Lietuva
}

\section{SANTRAUKA}

Po trumpu ir intensyvių fiziniu pratimu gali pasireikšti postaktyvacinè potenciacija (PAP) ir raumenu nuovargis. Valingo raumenų susitraukimo metu motoriniai vienetai rekrutuojami dažnių, sukeliančių nelygujji tetanusą. Būtent šie dažniai yra labiausiai veikiami postaktyvacinės potenciacijos, taip pat mažų dažniu nuovargio (MDN). Todèl ir norima šiuo tyrimu nustatyti, kuris iš fenomenų PAP ar MDN bus vyraujantis po $5 \mathrm{~s}$ trukmès maksimaliosios valingos jègos (MVJ) krūvio.

Tirti sveiki aktyviai nesportuojantys vyrai (amžius $24-35 \mathrm{~m}$., svoris $81,2 \pm 5,1 \mathrm{~kg})(\mathrm{n}=8)$. Tiriamieji atliko $5 \mathrm{~s}$ trukmès maksimalų izometrinį krūvi — kojos tiesimą per kelio sąnarị. Krūvio metu koja per kelio sąnarị fiksuota 90 laipsnių kampu. Keturgalvio šlaunies raumens susitraukimo jèga, sukelta 1, 7, 10, 15, 20 , $50 \mathrm{~Hz}$ ir $100 \mathrm{~Hz}$ stimuliavimo dažniu, buvo registruojama iš karto atlikus krūvị ir praejjus 3,5 ir 10 min po jo. Poilsio intervalai tarp stimulų $-3 \mathrm{~s}$.

Raumenų susitraukimo jèga, sukelta $1-15 \mathrm{~Hz}$ dažnio elektrostimuliavimo, iš karto po $5 \mathrm{~s}$ trukmès MVJ krūvio buvo reikšmingai didesnè nei prieš krūvị $(\mathrm{p}<0,01)$. Atsigavimo metu mažais dažniais sukelta jèga mažèjo. Praèjus 10 min po krūvio 15 ir $20 \mathrm{~Hz}$ dažnio sukelta jèga buvo reikšmingai mažesnè, lyginant su reikšme prieš krūvị $(\mathrm{p}<0,05)$. Raumenų susitraukimo jèga, sukelta $50 \mathrm{~Hz}$ ir $100 \mathrm{~Hz}$ dažnio, reikšmingai sumažejo tuoj pat po $5 \mathrm{~s}$ trukmès MVJ krūvio ir išliko sumažejusi 3 min $(\mathrm{p}<0,01)$. P 20 / P 50 santykis tuoj pat po $5 \mathrm{~s}$ MVJ krūvio reikšmingai padidèjo $(\mathrm{p}<0,05)$, tačiau praejjus 10 min po krūvio buvo reikšmingai mažesnis, palyginti su jo pradine reikšme $(\mathrm{p}<0,05)$.

Tyrimo rezultatai rodo, kad po $5 \mathrm{~s}$ trukmès maksimalaus valingo jègos krūvio konkuruoja du mechanizmai: nuovargis, mažinantis mažais ir dideliais stimuliavimo dažniais sukeltą raumenų susitraukimo jègą, ir postaktyvacinė potenciacija, didinanti mažų stimuliavimo dažnių sukeltą raumenų susitraukimo jẻgą. Išnykus postaktyvacinei potenciacijai (per 10 min po MVJ krūvio), sumažèja mažų stimuliavimo dažnių sukelta raumenų susitraukimo jëga, atsiranda mažu dažnių nuovargis.

Raktažodžiai: izometrinai pratimai, elektrostimuliacija, mažų dažnių nuovargis, atsigavimas.

Gauta 2007 m. lapkričio 13 d.

Received on November 13, 2007

Priimta $2008 \mathrm{~m}$. vasario $20 \mathrm{~d}$.

Accepted on February 20, 2008
Nerijus Masiulis

Lithuanian Academy of Physical Education

(Lietuvos kūno kultūros akademija)

Sporto 6, LT-44221 Kaunas

Lithuania (Lietuva)

Tel +37060039099

E-mailn.masiulis@1kka.lt 